\title{
Administration of Magnesium and its Association with Prevention of Ventricular Arrhythmias Following Cardiopulmonary Bypass in Open Heart Surgery
}

\author{
Md. Rezaul Karim¹, Tawfiq Ahmed², Bidyut Kumar Biswas ${ }^{3}$, Shahriar Moinuddin¹, \\ Md. Kamrul Hasan ${ }^{1}$, Asit Baran Adhikary ${ }^{4}$ \\ ${ }^{1}$ Department of Cardiac Surgery, NICVD, Dhaka, ${ }^{2}$ Department of Cardiac Surgery, \\ Sir Salimullah Medical College, Dhaka, ${ }^{3}$ Upazila Health Complex, Kabirhat, Sylhet, \\ ${ }^{4}$ Department of Cardiac Surgery, Bangabandhu Sheikh Mujib Medical University, Dhaka
}

\begin{abstract}
:
Key words: Magnesium, Background: The development of cardiac arrhythmias following open- heart surgery is fairly common. Hypomagnesemia appear to be a significant element in the genesis of postoperative ventricular arrhythmias. Ventricular Purpose of this study is to evaluate the effects of postoperative use of magnesium following cardiopulmonary bypass and minimize the risk of dreadful ventricular arrhythmia.

Arrhythmia, Methods: Total 80 (Eighty) patients were enrolled for this study divided in 2 groups, Group A ( $n=40)$ : Cardiopulmonary Bypass. patients who were given Magnesium Sulphate and Group B ( $n=40)$ : patients who were not given Magnesium. Monitoring of the patient in ICU was done for incidence of ventricular arrhythmias.

Results: From this study the incidence of postoperative ventricular arrhythmia was less in the magnesium treated group than the control group. Mean serum magnesium concentration decreased to subnormal value, immediately after surgery in both magnesium-treated and untreated groups.

Conclusions: Routine intravenous magnesium administration can reduce the incidence of ventricular arrhythmias after cardiac surgery following cardiopulmonary bypass.
\end{abstract}

(Cardiovasc. j. 2018; 11(1): 23-30)

\section{Introduction:}

Magnesium is the fourth most abundant mineral (cation) in the body. Fifty percent of the total body magnesium is found in bone and other $50 \%$ is found predominantly inside the cells of the body tissues and organs. While there is an absolute requirement for magnesium, the daily estimated average requirement (EAR) is $200 \mathrm{mg}$ for females and $250 \mathrm{mg}$ for males. ${ }^{1}$ Dietary magnesium is absorbed in the small intestine and excreted through the kidneys. ${ }^{2}$ It plays role on stabilizing the cellular transmembrane potential, suppressing excessive cellular calcium influx cation, preserving myocardial metabolites and reducing the severity of reperfusion injuries. ${ }^{3,4}$

Cardiopulmonary bypass (CPB) has become an indispensable technique for most cardiac surgical procedures. ${ }^{5}$ Initiation of $\mathrm{CPB}$ in adults causes acute hypomagnesaemia secondary to haemodilution. ${ }^{6}$

The development of cardiac arrhythmias following open- heart surgery is fairly common. Supraventricular arrhythmia, especially atrial fibrillation (AF), is noted frequently. Ventricular arrhythmias are less common, but warrant further evaluation and treatment because of their potentially life-threatening nature. Incidence of postoperative ventricular arrhythmia occur in 1-3\% of patients of cardiac surgery and carry a mortality rate of $20-30 \%$ and continue to be a major public health concern. ${ }^{7}$ England and coworkers reported that ventricular arrhythmia, more in hypomagnesemia following cardiopulmonary bypass. ${ }^{8}$

Magnesium plays a role in energy metabolism and cardiac impulse generation. Low levels have been associated with coronary spasm, low cardiac

Address of Correspondence: Dr. Md. Rezaul Karim, Department of Cardiac Surgery, NICVD, Dhaka, Bangladesh. Email-drrezanicvd@gmail.com 
output syndromes, prolonged ventilator support, a perioperative infarction, and a higher mortality rate, a higher incidence of postoperative atrial and ventricular arrhythmias. Ventricular arrhythmia include premature contraction, ventricular tachycardia and fibrillation. ${ }^{9}$ Magnesium deficiency results prolongation of the QT interval and enhanced vulnerability of ventricular arrhythmias. ${ }^{10}$

Postoperative ventricular arrhythmias (VT \& VF) are the immediate causes of sudden cardiac death. Hypomagnesemia appear to be a significant element in the genesis of postoperative ventricular arrhythmias. An increase in the serum magnesium concentration ranging from near normomagnesemic to slightly hypermagnesemic levels decrease in the incidence of ventricular arrhythmias. ${ }^{11}$ For this reason postoperative $\mathrm{Mg}^{++}$supplementation has been suggested in the prophylaxis of ventricular arrhythmias following cardiopulmonary bypass.

\section{Methods:}

This randomized clinical trial was done in the Department of Cardiac Surgery, National Institute of Cardiovascular Diseases and Hospital (NICVD), Dhaka from July 2016 to June 2017. The patients who were admitted into Cardiac Surgery Department fulfilling the inclusion and exclusion criteria were enrolled for the study. Inclusion criteria were all adult patient undergoing cardiac surgery under cardiopulmonary bypass with preoperatively in sinus rhythm. Patient with any forms of arrhythmias and abnormal serum magnesium level were excluded from the study. Total 80 (Eighty) patients were enrolled for this study divided in 2 groups, Group A ( $\mathrm{n}=40)$ : Patients who were given with $30 \mathrm{mg} / \mathrm{kg}$ of Magnesium Sulphate in $100 \mathrm{ml}$ of Normal saline over 10 minutes intravenously 4 hours after release of aortic cross clump (0, POD) and daily at $9.00 \mathrm{am}$ in 1st, 2nd and 3rd postoperative days and Group B $(n=40)$ : Patients who were not given Magnesium. Conventional treatment was given following CPB. Detailed history of each patient under the study, important and relevant findings on thorough physical examinations and investigations were recorded. Particular emphasis was given on history of taking beta blockers and other antiarrhythmic drugs and past history of myocardial infarction, congestive heart failure, diabetes mellitus, hypertension and chronic renal failure. After completion of the surgery with CPB. Patient was shifted to ICU with same inotropic support \& on ventilation. $30 \mathrm{mg} / \mathrm{kg}$ of Magnesium Sulphate in $100 \mathrm{ml}$ of Normal saline over 10 minutes given, ${ }^{12} 4$ hours after release of cross clamp (O POD) and at 9.00 a.m. in $1^{\text {st }}, 2^{\text {nd }}, 3^{\text {rd }}$ post-operative days in experimental group. 12 lead ECG was done before surgery and 8 hourly daily up to $3^{\text {rd }}$ postoperative day. Estimation of Serum magnesium including other electrolytes $(\mathrm{Na}+$, $\mathrm{K}+, \mathrm{Cl}-, \mathrm{HCO} 3-)$ was seen before surgery and before administration of magnesium and 4 hours after infusion of magnesium. Monitoring of the patients in ICU for ventricular arrhythmias was done. Ventilation time, duration of inotrope support and ICU stay were recorded in hours and compared between groups. Morbidity of patients like arrhythmia were recorded and compared between groups. In hospital mortality were recorded and compared between groups. All patients who survived were followed up for seven days. During follow up they were evaluated clinically and with the help of ECG. Statistical analyses were carried out by using SPSS 23.0 (Statistical Package for the Social Sciences by SPSS Inc., Chicago, IL, USA, 2015).

\section{Results:}

Total 80 patients were admitted for this study. Out of them, 40 patients were given with $30 \mathrm{mg} /$ $\mathrm{kg}$ of Magnesium Sulphate in $100 \mathrm{ml}$ of Normal saline over 10 minutes intravenously 4 hours after release of aortic cross clump and daily at $9 \mathrm{AM}$ in $1^{\text {st }}, 2^{\text {nd }}$ and $3^{\text {rd }}$ postoperative day (Group A) and 40 patients were not given Magnesium and conventional treatment was given following $\mathrm{CPB}$ (Group B). The mean age of group A patients was $45.6 \pm 11.5$ years \& of group B patients was $44.5 \pm 8.7$ years ranging from 18 to 55 years. Analysis revealed that no statistically significant between 2 groups regarding age of the patients $(p=0.670)$. There was no significant difference between the groups in terms of $\operatorname{sex}(p=0.648)$. But shows that there is a male dominance among the patients group A (Male $62.5 \%$ against female $37.5 \%$ ) and group B (Male 57.5\% against female $42.5 \%$ ). Out of 80 patients, $27.5 \%$ and $25.0 \%$ received $\beta$ blocker in group A and group B respectively. $\mathrm{Na}+$ channel blocker received 
$22.5 \%$ and $25.0 \%$ in group A and Group B respectively. $\mathrm{Ca}++$ channel blocker was $10.0 \%$ and $7.5 \%$ received in group A and group B respectively. Other anti-arrhythmic drugs received $17.5 \%$ in Group A and $15.0 \%$ in Group B. Anti-arrhythmic drug not taken were $22.5 \%$ and $27.5 \%$ in group A and group B respectively. Analysis revealed that no statistically significant difference was found between two groups of patients $(\mathrm{p}>0.05)$. (Table I)

The mean percent of ejection fraction was $55.4 \pm 7.3$ and $56.3 \pm 5.9$ in group $A$ and in group B respectively. Analysis showed that no statistically significant mean difference was found between two groups of patients ( $>>0.05)$, the mean percent of ejection fraction was low in group A patients compared to group B patients. (Table II)

Table III shows the VA (ECG) of the studied patients. Among group A patients 5.0\% found VA positive (PVC $2.5 \%$, VT $1.0 \%$ and VF $0 \%$ ) and rest 95.0\% VA negative. Among group B VA positive were found in $22.5 \%$ cases (PVC $12.5 \%$, VT $5.0 \%$ and VF 5.0\%), whereas $78.5 \%$ VA negative. VA positive cases were higher in group B compare to group A which is statistically significant.

The mean $\mathrm{Mg}^{++}$was $1.9 \pm 0.2$ and $1.7 \pm 0.2$ in Group A and Group B respectively during POD0. The mean $\mathrm{Mg}^{++}$was $2.0 \pm 0.2$ and $1.7 \pm 0.2$ in Group A and Group B respectively during POD1. The mean $\mathrm{Mg}^{++}$was $2.1 \pm 0.2$ and $1.7 \pm 0.2$ in Group A and Group B respectively during POD2. The mean $\mathrm{Mg}^{++}$was $2.3 \pm 0.1$ and $2.1 \pm 0.2$ in Group A and Group B respectively during POD3.

The mean $\mathrm{Mg}^{++}$was $1.6 \pm 0.1$ and $1.9 \pm 0.2$ in before and after supplementation respectively in Group A during POD 0 . The mean $\mathrm{Mg}^{++}$was $1.8 \pm 0.2$ and $2.0 \pm 0.2$ in before and after supplementation respectively in Group A during POD1. The mean $\mathrm{Mg}^{++}$was $1.9 \pm 0.2$ and $2.1 \pm 0.2$ in before and after supplementation respectively in Group A during POD2. The mean $\mathrm{Mg}^{++}$was $2.0 \pm 0.1$ and $2.3 \pm 0.1$ in before and after supplementation respectively in Group A during POD3. The mean difference was statistically significant $(\mathrm{p}<0.05)$ between before and after supplementation of $\mathrm{Mg}^{++}$in Group A in POD 0, POD1, POD2 and POD3. (Table-VI)

The mean duration of ICU stay was $4.6 \pm 1.6$ ranging from 4-5 days and 5.2 \pm 1.6 ranging from 4-6 days in group A and group B respectively. The mean duration of hospital stay was $10.7 \pm 2.8$ ranging from 8-12 days and 11.6 \pm 3.8 ranging from 9-14 days in group A and group B respectively. The difference of all parameters were not statistically significant $(p>0.05)$ between group $\mathrm{A}$ and group B. (Table-VII)

Table-I

Distribution of patients according to their drug received $(N=80)$.

\begin{tabular}{|c|c|c|c|c|c|}
\hline \multirow[t]{2}{*}{ Drug received before operation } & \multicolumn{2}{|c|}{$\begin{array}{c}\text { Group A } \\
(\mathrm{n}=40)\end{array}$} & \multicolumn{2}{|c|}{$\begin{array}{c}\text { Group B } \\
(\mathrm{n}=40)\end{array}$} & \multirow[t]{2}{*}{$\mathrm{p}$ value } \\
\hline & No. & $\%$ & No. & $\%$ & \\
\hline b blocker (Atenolol, Bisoprolol, Esmolol, Propranolol) & 11 & 27.5 & 10 & 25.0 & $0.971^{\mathrm{ns}}$ \\
\hline Na+ channel blocker (Lignocaine) & 9 & 22.5 & 10 & 25.0 & \\
\hline Other anti-arrhythmic (Digoxin, Amiodaron) & 7 & 17.5 & 6 & 15.0 & \\
\hline $\mathrm{Ca}^{++}$channel blocker (Verapamil, Diltiazem) & 4 & 10.0 & 3 & 7.5 & \\
\hline Not taken & 9 & 22.5 & 11 & 27.5 & \\
\hline Total & 40 & 100.0 & 40 & 100.0 & \\
\hline
\end{tabular}

Group A: Magnesium treated group $\quad$ NS = Not significant Group B: Control group

Table-II

Mean percent of ejection fraction of the study patients $(N=80)$.

\begin{tabular}{|c|c|c|c|c|c|}
\hline \multirow[t]{2}{*}{ Ejection fraction } & \multicolumn{2}{|c|}{$\begin{array}{c}\text { Group A } \\
(n=40)\end{array}$} & \multicolumn{2}{|c|}{$\begin{array}{c}\text { Group B } \\
(\mathrm{n}=40)\end{array}$} & \multirow[t]{2}{*}{$p$ value } \\
\hline & No. & $\%$ & No. & 0 & \\
\hline$\overline{\mathrm{Mean}} \pm \mathrm{SD}$ & \multicolumn{2}{|c|}{$55.4 \pm 7.3$} & \multicolumn{2}{|c|}{$56.3 \pm 5.9$} & $0.546^{\mathrm{ns}}$ \\
\hline
\end{tabular}

Group A: Magnesium treated group

Group B: Control group

$\mathrm{NS}=$ Not significant 


\section{Table-III}

Distribution of patients by ventricular arrhythmia (ECG)- VA (PVC, VT, VF).

\begin{tabular}{|c|c|c|c|c|c|}
\hline \multirow[t]{2}{*}{$\overline{\mathrm{VA}(\mathrm{PVC}, \mathrm{VT}, \mathrm{VF})}$} & \multicolumn{2}{|c|}{$\begin{array}{c}\text { Group A } \\
(\mathrm{n}=40)\end{array}$} & \multicolumn{2}{|c|}{$\begin{array}{c}\text { Group B } \\
(\mathrm{n}=40)\end{array}$} & \multirow[t]{2}{*}{$p$ value } \\
\hline & No. & $\%$ & No. & $\%$ & \\
\hline Positive & 2 & 5.0 & 9 & 22.5 & $0.023^{\mathrm{s}}$ \\
\hline PVC & 1 & 2.5 & 5 & 12.5 & \\
\hline $\mathrm{VT}$ & 1 & 2.5 & 2 & 5.0 & \\
\hline VF & 0 & 0 & 2 & 5.0 & \\
\hline Negative & 38 & 95.0 & 31 & 77.5 & \\
\hline Total & 40 & 100.0 & 40 & 100.0 & \\
\hline
\end{tabular}

Group A: Magnesium treated group $\quad$ S = Significant

Group B: Control group

Table-IV

$\mathrm{Na}^{+}, \mathrm{K}^{+}, \mathrm{Mg}^{++}, \mathrm{CI}^{-}, \mathrm{HCO}_{3}-$ and $\mathrm{Mg}^{++}$status before supplementation of the study subjects (N=80).

\begin{tabular}{cccc}
\hline & $\begin{array}{c}\text { Group A } \\
(\mathrm{n}=40) \\
\text { Mean } \pm \text { SD }\end{array}$ & $\begin{array}{c}\text { Group B } \\
(\mathrm{n}=40) \\
\text { Mean } \pm \mathrm{SD}\end{array}$ & p value \\
\hline $\mathrm{Na}^{+}(\mathrm{mmol} / \mathrm{L})$ & & & \\
POD 0 & $141.9 \pm 2.9$ & $143.1 \pm 2.7$ & $0.061^{\mathrm{ns}}$ \\
POD 1 & $141.4 \pm 2.8$ & $142.1 \pm 2.6$ & $0.189^{\mathrm{ns}}$ \\
POD 2 & $143.3 \pm 2.9$ & $144.1 \pm 2.4$ & $0.183^{\mathrm{ns}}$ \\
POD 3 & $144.3 \pm 2.6$ & $145.2 \pm 2.4$ & $0.117^{\mathrm{ns}}$ \\
$\mathrm{K}^{+}(\mathrm{mm} / \mathrm{L})$ & & & \\
POD 0 & $3.9 \pm 0.2$ & $3.8 \pm 0.2$ & $0.081^{\mathrm{ns}}$ \\
POD 1 & $4.2 \pm 0.3$ & $3.9 \pm 0.2$ & $0.746^{\mathrm{ns}}$ \\
POD 2 & $3.8 \pm 0.4$ & $4.2 \pm 0.1$ & $0.982^{\mathrm{ns}}$ \\
POD 3 & $4.2 \pm 0.2$ & $3.9 \pm 0.2$ & \\
$\mathrm{Mg}^{++}(\mathrm{mg} / \mathrm{dl})$ & & & $0.166^{\mathrm{ns}}$ \\
POD 0 & $1.6 \pm 0.1$ & $1.7 \pm 0.2$ & $0.157^{\mathrm{ns}}$ \\
POD 1 & $1.8 \pm 0.2$ & $1.5 \pm 0.2$ & $0.157^{\mathrm{ns}}$ \\
POD 2 & $1.9 \pm 0.2$ & $1.6 \pm 0.1$ & \\
POD 3 & $2.0 \pm 0.1$ & $2.1 \pm 0.2$ & $0.805^{\mathrm{ns}}$ \\
$\mathrm{CI}^{-}(\mathrm{mm} / \mathrm{L})$ & & & $0.931^{\mathrm{ns}}$ \\
POD 0 & $101.4 \pm 1.8$ & $101.2 \pm 1.6$ & $0.285^{\mathrm{ns}}$ \\
POD 1 & $102.5 \pm 1.6$ & $101.2 \pm 1.5$ & $0.831^{\mathrm{ns}}$ \\
POD 2 & $104.5 \pm 1.7$ & $103.1 \pm 1.6$ & $0.807^{\mathrm{ns}}$ \\
POD 3 & $103.4 \pm 1.6$ & $102.2 \pm 1.4$ & $0.323^{\mathrm{ns}}$ \\
(mmol/L) & & & \\
POD 0 & $23.2 \pm 1.1$ & $24.2 \pm 1.2$ & $25.3 \pm 1.3$ \\
POD 1 & $25.5 \pm 1.2$ & $27.4 \pm 1.1$ &
\end{tabular}

Group A: Magnesium treated group NS = Not significant

Group B: Control group 


\section{Table-V}

$\mathrm{Na}^{+}, \mathrm{K}^{+}, \mathrm{Mg}^{++}, \mathrm{CI}, \mathrm{HCO}_{3}$ and $\mathrm{Mg}^{++}$status after supplementation of the study subjects $(\mathrm{N}=80)$.

\begin{tabular}{|c|c|c|c|}
\hline & $\begin{array}{c}\text { Group A } \\
(\mathrm{n}=40) \\
\text { Mean } \pm \text { SD }\end{array}$ & $\begin{array}{c}\text { Group B } \\
(\mathrm{n}=40) \\
\operatorname{Mean} \pm \mathrm{SD}\end{array}$ & $\mathrm{p}$ value \\
\hline \multicolumn{4}{|l|}{$\overline{\mathrm{Na}^{+}(\mathrm{mmol} / \mathrm{L})}$} \\
\hline POD 0 & $141.7 \pm 2.9$ & $142.1 \pm 2.7$ & $0.526^{\mathrm{ns}}$ \\
\hline POD 1 & $139.8 \pm 2.6$ & $143.1 \pm 2.6$ & $0.769^{\mathrm{ns}}$ \\
\hline POD 2 & $143.3 \pm 2.5$ & $144.1 \pm 2.5$ & $0.289^{\mathrm{ns}}$ \\
\hline \multicolumn{4}{|l|}{$\mathrm{K}^{+}(\mathrm{mmol} / \mathrm{L})$} \\
\hline POD 0 & $3.9 \pm 0.2$ & $3.8 \pm 0.1$ & $0.554^{\mathrm{ns}}$ \\
\hline POD 1 & $4.2 \pm 0.3$ & $3.9 \pm 0.2$ & $0.660^{\mathrm{ns}}$ \\
\hline POD 2 & $3.8 \pm 0.4$ & $4.2 \pm 0.1$ & $0.469^{\mathrm{ns}}$ \\
\hline POD 3 & $4.2 \pm 0.2$ & $3.9 \pm 0.1$ & $0.542^{\mathrm{ns}}$ \\
\hline \multicolumn{4}{|l|}{$\mathrm{Mg}^{++}(\mathrm{mg} / \mathrm{dl})$} \\
\hline POD 0 & $1.9 \pm 0.2$ & $1.7 \pm 0.2$ & $0.001^{\mathrm{s}}$ \\
\hline POD 1 & $2.0 \pm 0.2$ & $1.7 \pm 0.2$ & $0.001^{\mathrm{s}}$ \\
\hline POD 2 & $2.1 \pm 0.2$ & $1.7 \pm 0.2$ & $0.001^{\mathrm{s}}$ \\
\hline POD 3 & $2.3 \pm 0.1$ & $2.1 \pm 0.2$ & $0.001^{\mathrm{s}}$ \\
\hline \multicolumn{4}{|l|}{$\mathrm{CI}^{-}(\mathrm{mmol} / \mathrm{L})$} \\
\hline POD 0 & $101.4 \pm 1.8$ & $101.2 \pm 1.5$ & $0.554^{\mathrm{ns}}$ \\
\hline POD 1 & $102.5 \pm 1.7$ & $101.2 \pm 1.6$ & $0.674^{\mathrm{ns}}$ \\
\hline POD 2 & $104.5 \pm 1.6$ & $103.1 \pm 1.5$ & $0.326^{\mathrm{ns}}$ \\
\hline POD 3 & $103.4 \pm 1.5$ & $102.2 \pm 1.4$ & $0.923^{\mathrm{ns}}$ \\
\hline \multicolumn{4}{|l|}{$\mathrm{HCO}_{3}^{-}(\mathrm{mmol} / \mathrm{L})$} \\
\hline POD 0 & $23.2 \pm 1.1$ & $24.2 \pm 1.2$ & $0.242^{\mathrm{ns}}$ \\
\hline POD 1 & $25.5 \pm 1.2$ & $25.3 \pm 1.3$ & $0.529^{\mathrm{ns}}$ \\
\hline POD 2 & $23.9 \pm 1.3$ & $27.4 \pm 1.3$ & $0.383^{\mathrm{ns}}$ \\
\hline POD 3 & $25.6 \pm 1.1$ & $24.1 \pm 1.4$ & $0.608^{\mathrm{ns}}$ \\
\hline
\end{tabular}

Group A : Magnesium treated group $\quad \mathrm{S}=$ Significant $\quad \mathrm{NS}=$ Not significant

Group B : Control group

Table-VI

Comparison of Magnesium administration between before supplementation and after supplementation in Group A patients.

\begin{tabular}{lccc}
\hline & $\begin{array}{c}\text { Before supplementation } \\
(\mathrm{n}=40) \\
\text { mean } \pm \mathrm{SD}\end{array}$ & $\begin{array}{c}\text { After supplementation } \\
(\mathrm{n}=40) \\
\text { mean } \pm \mathrm{SD}\end{array}$ & p value \\
\hline POD 0 & $1.6 \pm 0.1$ & $1.9 \pm 0.2$ & $<0.001^{\mathrm{s}}$ \\
POD 1 & $1.8 \pm 0.2$ & $2.0 \pm 0.2$ & $<0.001^{\mathrm{s}}$ \\
POD 2 & $1.9 \pm 0.2$ & $2.1 \pm 0.2$ & $<0.001^{\mathrm{s}}$ \\
POD 3 & $2.0 \pm 0.1$ & $2.3 \pm 0.1$ & $<0.001^{\mathrm{s}}$ \\
\hline
\end{tabular}

Group A: Magnesium treated group $\quad \mathrm{S}=$ Significant

Group B: Control group 
Table-VII

Comparison of ICU stay, hospital stay between two groups $(n=80)$.

\begin{tabular}{lccc}
\hline & Group A & Group B & p value \\
& $\begin{array}{c}\text { mean } \pm \text { SD } \\
\text { Range (min, max) }\end{array}$ & Range (min, max) & \\
\hline ICU stay (days) Range & $4.6 \pm 1.6$ & $5.2 \pm 1.6$ & $0.090^{\text {ns }}$ \\
& $(4-5)$ & $(4-6)$ & \\
Hospital stay (days)Range & $10.7 \pm 2.8$ & $11.6 \pm 3.8$ & $0.231^{\mathrm{ns}}$ \\
& $(8-12)$ & $(9-14)$ & \\
\hline
\end{tabular}

Group A: Magnesium treated group

$\mathrm{S}=$ Significant

$\mathrm{NS}=$ Not significant

Group B: Control group

\section{Discussion:}

40 patients were treated with magnesium and patients underwent cardiopulmonary bypass while other 40 were not treated with magnesium. Based on this study, MgSO4 significantly decreased the incidence of arrhythmia at patients who underwent elective cardiac surgery. $\mathrm{Mg}^{++}$compared with placebo, decreased the incidence of arrhythmia up to $59 \%$.

In this study the mean age of Magnesium treated group patients were $45.6 \pm 11.5$ years ranging from 18 to 55 years and Group B patients were $44.5 \pm 8.7$ years ranging from 18 to 55 years. Analysis revealed that no statistically significant mean age difference was found between Group A and Group B patients ( $>0.05$ ). It was found that among Group A patients, highest percentage (50.0\%) had age group 41-50 years, whereas among Group B highest percentage (52.5\%) had age group 41-50 years. Naghipour and his colleagues reported mean age 59.6 years. ${ }^{13}$ Hazelrigg and his colleagues seen that mean age of experimental group was $62.1 \pm 9.5$ years and control group $63.7 \pm 11.1$ years which is $\mathrm{NS}^{14}$ Toraman and his colleagues seen that mean age of magnesium group $62 \pm 6.7$ years and control group $61.4 \pm 8.7$ years, where $\mathrm{p}=0.56 .^{15}$

In present study, the mean percent of ejection fraction was $55.4 \pm 7.3$. It was $56.3 \pm 5.9$ in magnesium treated group and in control group respectively. Analysis showed that no statistically significant mean difference was found between two groups of patients $(p>0.05)$, the mean percent of ejection fraction was low in group A patients compared to group B patients. It was found that the proportion of mean percent ejection fraction less than 50 was higher in group
A patients (15.0\%) than group B patients (10.0\%). On the contrary, the mean percent of ejection fraction 50-60 was higher in group B patients (65.0) than group A patients (60.0\%) and the mean percent of ejection fraction $>60$ was equal in both group (25.0\%). Vaziri and his colleagues reported similar findings. 16

In present study showed the VA (ECG) of the studied patients. Among group A patients 5.0\% found VA positive (PVC 2.5\%, VT 2.5\% and VF $0 \%)$ and rest $95.0 \%$ VA negative. Among group B VA positive were found in $22.5 \%$ cases (PVC $12.5 \%$, VT $5.0 \%$ and VF $5.0 \%$ ), whereas $78.5 \%$ VA negative. VA positive cases were higher in group B compare to group A and statistically significant.

The mean difference of $\mathrm{Mg}^{++}$was statistically significant $(p<0.05)$ between Group A and Group $\mathrm{B}$ patients postoperatively on $0,01,02$ and 03 POD and other electrolytes difference were statistically not significant $(p>0.05)$ between 2 groups.

In a study Hazelrigg and his colleagues $\mathrm{Mg}^{++}$level in the experimental \& control group was $2.07 \&$ 2.09 (on admission), 3.05\& 1.7 (POD\#0), $3.15 \&$ 1.69 (POD\#1), $3.99 \& 1.91$ (POD\#2) and $2.63 \&$ 2.13 (POD\#3). ${ }^{14}$

In our study the mean $\mathrm{Mg}^{++}$was $1.6 \pm 0.1$ and $1.9 \pm 0.2$ in before and after supplementation respectively in Group A during POD0. The mean $\mathrm{Mg}^{++}$was $1.8 \pm 0.2$ and $2.0 \pm 0.2$ in before and after supplementation respectively in Group A during POD1. The mean $\mathrm{Mg}^{++}$was $1.9 \pm 0.2$ and $2.1 \pm 0.2$ in before and after supplementation respectively in Group A during POD2. The mean $\mathrm{Mg}^{++}$was $2.0 \pm 0.1$ and $2.3 \pm 0.1$ in before and after 
supplementation respectively in Group A during POD3. The mean difference was statistically significant $(\mathrm{p}<0.05)$ between before and after supplementation of $\mathrm{Mg}^{++}$in Group A in POD 0, POD1, POD2 and POD3.

In present study, the mean duration of ICU stay was $4.6 \pm 1.6$ ranging from $4-5$ days and $5.2 \pm 1.6$ ranging from 4-6 days in group A and group B respectively. The mean duration of hospital stay was $10.7 \pm 2.8$ ranging from 8 - 12 days and $11.6 \pm 3.8$ ranging from 9-14 days in group A and group B respectively. The difference of all parameters was not statistically significant $(p>0.05)$ between group A and group B. In a study of Kohna and his colleagues the mean duration of hospital stay was $17.7 \pm 6.6$ days and $16.3 \pm 7.5$ days in Group A and Group B respectively.

In a comparison of our results, Tiryakioglu and his colleagues showed the prophylactic use of MgSO4 is effective at preventing arrhythmia that may occur following cardiopulmonary bypass. Some meta-analysis investigated the effect of $\mathrm{Mg}^{++}$about the prevention of arrhythmia after cardiac surgery. Burgess et al. examine trials that verified the effect of $\mathrm{Mg}^{++}$to prevent postoperative ventricular arrhythmia. Based on their meta-analysis, $\mathrm{Mg}^{++}$prevents postoperative ventricular arrhythmia, but there was a significant heterogeneity between trials. The source of heterogeneity partly was explained by concomitant use of beta-blockers. Furthermore, the lack of data about the incidence of VF and VT was their major limitation. The result of our study is similar to this meta-analysis, but we verified the effect of $\mathrm{Mg}^{++}$on all type of arrhythmias such as VF, VT, premature ventricular complex, premature atrial complex, and junctional rhythms. Based on our study, prophylactic $\mathrm{Mg}^{++}$decreased all type of arrhythmias such as PVC, VT and VF. ${ }^{17}$

\section{Conclusion:}

From this study the incidence of postoperative ventricular arrhythmia was less in the magnesium treated group than the control group. Mean serum magnesium concentration decreased to subnormal value, immediately after surgery in both magnesium-treated and untreated groups. No adverse effect of magnesium infusion was detected in any of the patients receiving the treatment. From this study we concluded that routine intravenous magnesium administration can reduce the incidence of ventricular arrhythmias following cardiopulmonary bypass in cardiac surgery.

\section{Conflict of Interest - None.}

\section{References:}

1. Fawcett WJ, Haxby EJ, Male DA. Magnesium physiology and pharmacology. BJA: British Journal of Anaesthesia 1999; 83: 302-320.

2. Percival S, Rude R, Weaver C, Whelan. E 12/5/2005, 'Magnesium', Office of the Dietary Supplements, National Institute of Health, Betherda, Maryland 20892, USA ,Available: file:/!F:N Magnesium 2.htm (Accessed:8/2/2017).

3. Yang Q, Liu YC, Zou W, Yim APC, He GW. Protective effect of Magnesium on the endothelial function mediated by endothelium-derived hyperpolarizing factor in coronary arteries during cardioplegic arrest in a porcine model. $I$ Thorac Cardiovasc Surg 2002; 124: 361-370.

4. Chakraborti S, Chakraborti T, Mandal M, Mandal A, Das $\mathrm{S}$, Ghosh S. Protective role of magnesium in cardiovascular diseases: a review. Mol Biochem 2002; 238: 163-179.

5. Cardiopulmonary bypass: Technique and pathophysiology. In: Sellke F, del Nido PJ, Swanson SJ. Eds. Sabiston \& Spencer Surgery of the chest, $9^{\text {th }}$ ed. Philadelphia: Saunders Elsevier; 2016: 957.

6. Satur C. Magnesium and Its Role in Cardiac Surgical Practice: A Review. J Clin Basic Cardiol 2002; 5: 67-72.

7. Yeuing-Lai-Wah J, Qi A, McNeil E. New-onset sustained ventricular tachycardia and fibrillation early after cardiac operations. Ann Thorac Surg 2004; 77: 2083-2088.

8. England M, Gordon G, Salem M, Chernow B. Magnesium administration and dysrhythmias after cardiac surgery. A placebo-controlled, double-blind, randomized trial. JAMA 1992; 268: 2395-2402.

9. Booth J, Phillips-Bute B, McCants C. Low serum magnesium level predicts adverse cardiac events after coronary artery bypass graft. Am Heart $J$ 2003; 145: 1108-1113.

10. Parikka H, Toivonen L, Naukkarinen V, Tierala I, PohjolaSintonen S, Heikkla J. Decreases by magnesium of QT dispersion and ventricular arrhythmias in patients with acute myocardial infarction. Eur Heart $J$ 1999; 20: 111-120.

11. Yurvati A, Sanders S, Dullye L, Carney M, Archer R, Koro P. Antiarrhythmic response to intravenously administered magnesium after cardiac surgery. Southern Med J 1992; 85: 714-717.

12. Verma Y, Chauhan S, Garde P, Laxkshmy R, Kiran, U. Role of magnesium in the prevention of postoperative 
arrhythmias in neonates and infants undergoing arterial switch operation. Interactive Cardiovasc Thorac Surg 2010; 11: $537-576$

13. Naghipour B, Faridaalaee G, Shadvar K, Bilehjani E, Khabaz A, Fakhari S. Effect of prophylaxis of magnesium sulfate for reduction of postcardiac surgery arrhythmia: Randomized clinical trial. Ann Card Anaesth 2016; 19: 662-667.

14. Hazelrigg S, Boley T, Cetindag I. Cardiac Arrhythmias in Cardiovascular Management. In: Rovert M, Bojar. Eds. Manual of Perioperative care in Adult Cardiac Surgery, $5^{\text {th }}$ Edition. Massachusetts, USA: Blackwell Publishing, 2005: 529-564.
15. Toraman F, Karabulut E, Alhan H, Dagdelen S, Tarcan S. Magnesium Infusion Dramatically Decreases the Incidence of Atrial Fibrillation After Coronary Artery Bypass Grafting. Ann Thorac Surg 2001; 72: 1256-1262.

16. Vaziri M, Jouibar R, Akhlagh S, Janati M. The Effect of Lidocaine and Magnesium Sulfate on Prevention of Ventricular Fibrillation in Coronary Artery Bypass Grafting Surgery. Iranian Red Crescent Medical Journal 2010; 12: 298-301.

17. Tiryakioglu O, Sinan D, Hasan A, Selma K, Kagan H, Ozer S. Magnesium sulphate and amiodarone prophylaxis for prevention of postoperative arrhythmia in coronary by-pass operations. J Cardiothorac Surg 2009, 4: 8. 